\title{
Physical controls on the storage of methane in landfast sea ice
}

\author{
J. Zhou ${ }^{1,2}$, J.-L. Tison ${ }^{1}$, G. Carnat ${ }^{1}$, N.-X. Geilfus ${ }^{3}$, and B. Delille ${ }^{2}$ \\ ${ }^{1}$ Laboratoire de glaciologie, DSTE, Université Libre de Bruxelles, Brussels, Belgium \\ ${ }^{2}$ Unité d'Océanographie chimique, MARE, Université de Liège, Liège, Belgium \\ ${ }^{3}$ Arctic Research Center, Aarhus University, Aarhus, Denmark
}

Correspondence to: J. Zhou (jiayzhou@ulb.ac.be)

Received: 13 November 2013 - Published in The Cryosphere Discuss.: 6 January 2014

Revised: 17 April 2014 - Accepted: 22 April 2014 - Published: 3 June 2014

\begin{abstract}
We report on methane $\left(\mathrm{CH}_{4}\right)$ dynamics in landfast sea ice, brine and under-ice seawater at Barrow in 2009. The $\mathrm{CH}_{4}$ concentrations in under-ice water ranged from 25.9 to $116.4 \mathrm{nmol} \mathrm{L}_{\mathrm{sw}}^{-1}$, indicating a supersaturation of 700 to $3100 \%$ relative to the atmosphere. In comparison, the $\mathrm{CH}_{4}$ concentrations in sea ice ranged from 3.4 to $17.2 \mathrm{nmol} \mathrm{L}_{\text {ice }}^{-1}$ and the deduced $\mathrm{CH}_{4}$ concentrations in brine from 13.2 to $677.7 \mathrm{nmol} \mathrm{L}_{\text {brine }}^{-1}$. We investigated the processes underlying the difference in $\mathrm{CH}_{4}$ concentrations between sea ice, brine and under-ice water and suggest that biological controls on the storage of $\mathrm{CH}_{4}$ in ice were minor in comparison to the physical controls. Two physical processes regulated the storage of $\mathrm{CH}_{4}$ in our landfast ice samples: bubble formation within the ice and sea ice permeability. Gas bubble formation due to brine concentration and solubility decrease favoured the accumulation of $\mathrm{CH}_{4}$ in the ice at the beginning of ice growth. $\mathrm{CH}_{4}$ retention in sea ice was then twice as efficient as that of salt; this also explains the overall higher $\mathrm{CH}_{4}$ concentrations in brine than in the under-ice water. As sea ice thickened, gas bubble formation became less efficient, $\mathrm{CH}_{4}$ was then mainly trapped in the dissolved state. The increase of sea ice permeability during ice melt marked the end of $\mathrm{CH}_{4}$ storage.
\end{abstract}

\section{Introduction}

Methane $\left(\mathrm{CH}_{4}\right)$ is a well-mixed greenhouse gas. Its concentration in the atmosphere is much lower than that of its oxidation product $\left(\mathrm{CO}_{2}\right)$ (1.9 vs. $397 \mathrm{ppm}$ respectively) (http: //www.esrl.noaa.gov/gmd/aggi/). However, since the $\mathrm{CH}_{4}$ global warming potential is 28 times higher than that of $\mathrm{CO}_{2}$ over a 100-year frame, it accounts for $20 \%$ of the global radiative forcing of well-mixed greenhouse gases (Myhre et al., 2013).

Global ocean emission of $\mathrm{CH}_{4}$ is estimated at $19 \mathrm{Tg}$ per year (Kirschke et al., 2013), which is about $3 \%$ of the global tropospheric $\mathrm{CH}_{4}$ input. Of that marine contribution, $75 \%$ is from coastal regions (Bange et al., 1994). $\mathrm{CH}_{4}$ supersaturation relative to the atmosphere in estuaries (Borges and Abril, 2011; Upstill-Goddard et al., 2000) and coastal shelves (Kvenvolden et al., 1993; Savvichev et al., 2004; Shakhova et al., 2005, 2010) is indeed larger than that in the open ocean (Bates et al., 1996; Damm et al., 2007, 2008, 2010).

Methanogenesis in submarine sediments is thought to be the main process causing $\mathrm{CH}_{4}$ efflux in the Arctic shelf regions. Nonetheless, other sources could also be significant: $\mathrm{CH}_{4}$ seepage from coastal ice-complex deposits (Romanovskii et al., 2000) and from deeper seabeds (Judd, 2004), and $\mathrm{CH}_{4}$ dissociation in the shallow hydrates (Reagan and Moridis, 2008; Westbrook et al., 2009). Recently, aerobic $\mathrm{CH}_{4}$ production in the water column related to dimethylsulfoniopropionate (DMSP) degradation was reported for the central Arctic (Damm et al., 2010), tropical upwelling areas (Florez-Leiva et al., 2013) and tropical oligotrophic areas (Zindler et al., 2013). However, the significance of that process over the Arctic shelf still needs to be assessed.

Ongoing global warming is likely to affect the various sources of $\mathrm{CH}_{4}$ cited above, with positive feedback on the climate. Indeed, a rise in sea temperature should increase methanogenic activities, leading to a more efficient conversion of organic matter to $\mathrm{CH}_{4}$ (Zeikus and Winfrey, 1976). In addition, the induced seawater stratification is likely to change the nutrient ratio, which favours aerobic $\mathrm{CH}_{4}$ production (Karl et al., 2008). Moreover, warmer seawater is likely to weaken the coastal ice complex (including subsea 
permafrost) (Lawrence et al., 2008) and to displace the gas hydrate stability zones (Reagan and Moridis, 2008), increasing gas seepage. Significant $\mathrm{CH}_{4}$ escape has recently been detected via acoustic surveys along the Spitsbergen continental margin (Westbrook et al., 2009), suggesting that changes in the $\mathrm{CH}_{4}$ storage system are ongoing. Since $\mathrm{CH}_{4}$ has a high global warming potential, its release will enhance global warming, which in turn will enhance methanogenic activities and gas seepages. This positive feedback has contributed to rapid and significant climate warming in the past (O'Connor et al., 2010).

Understanding the current $\mathrm{CH}_{4}$ budget is thus important in order to better simulate future climate scenarios. Many $\mathrm{CH}_{4}$ measurements have been carried out in sediments and seawater throughout the coastal Arctic areas (Kvenvolden et al., 1993; Savvichev et al., 2004; Shakhova et al., 2005, 2010). These observations have led to speculations about potential $\mathrm{CH}_{4}$ accumulation (Shakhova et al., 2010) and/or oxidation (Kitidis et al., 2010) under sea ice cover. Other studies further brought forward the role of sea ice in the exchange of $\mathrm{CH}_{4}$ between seawater and the atmosphere (He et al., 2013; Kort et al., 2012). However, to the best of our knowledge, no study has yet discussed the physical controls on the storage of $\mathrm{CH}_{4}$ in sea ice and its exchange at the atmosphere-ice-ocean interfaces. For instance, $\mathrm{CH}_{4}$ mixing ratios up to $11000 \mathrm{ppmV}$ have been measured in sea ice bubbles (Shakhova et al., 2010), but the mechanisms leading to the incorporation of those gas bubbles within the ice have not been discussed. Similarly, $\mathrm{He}$ et al. (2013) suggested $\mathrm{CH}_{4}$ consumption in the ice, based on $\mathrm{CH}_{4}$ fluxes above sea ice. However, they did not discuss the impact of sea ice permeability or ice melt on their results, although these parameters have been shown to affect other gas dynamics in sea ice (see, e.g., Loose et al. (2009) for $\mathrm{O}_{2}$ and $\mathrm{SF}_{6}$, Geilfus et al. (2012) and Nomura et al. (2010) for $\mathrm{CO}_{2}$, and Zhou et al. (2013) for Ar). Therefore, we felt it necessary to highlight the physical controls on $\mathrm{CH}_{4}$ dynamics in sea ice, from ice growth to ice melt. We have done this by investigating the annual evolution of $\mathrm{CH}_{4}$ concentrations in sea ice, in parallel with sea ice physical properties, and $\mathrm{CH}_{4}$ concentrations in seawater. To the best of our knowledge, we report here the first detailed time series of $\mathrm{CH}_{4}$ concentrations in sea ice across seasons.

\section{Materials and methods}

\subsection{Study site and physical framework}

Sea ice and under-ice seawater samples were collected during a field survey in the Chukchi Sea near Barrow (Alaska) (Fig. 1) from January through June 2009. The sampling was performed on level first-year landfast sea ice, within a square of $50 \mathrm{~m}$ by $50 \mathrm{~m}$. The north-eastern corner of the square was located at $71^{\circ} 22.013^{\prime} \mathrm{N}, 156^{\circ} 32.447^{\prime} \mathrm{W}$. Seawater depth at the location was about $6.5 \mathrm{~m}$ (http://seaice.alaska.edu/gi/



Figure 1. The study site (north of Barrow, Alaska, USA).

observatories/barrow_sealevel). Ice cores were extracted and kept in darkness in the laboratory at $-35^{\circ} \mathrm{C}$ to prevent brine drainage and to limit biological activity. Temperature recorders indicated that the samples were always kept below $-20^{\circ} \mathrm{C}$ during transport. All of the analyses were completed within the following year. A complete physical framework of the present study is presented and discussed in Zhou et al. (2013). We have selected six sampling events to illustrate the evolution of $\mathrm{CH}_{4}$ concentrations at our location: one in the winter (BRW2; 3 February), four in early spring (BRW4, BRW5, BRW6 and BRW7; corresponding to 31 March, 3, 7 and 10 April respectively), and the final one in late spring (BRW10; 5 June). The first five sampling events occurred during ice growth, the last one during ice decay.

\section{2 $\mathrm{CH}_{4}$ concentrations in seawater}

$\mathrm{CH}_{4}$ concentrations in seawater were determined by gas chromatography (GC) with flame ionization detection (SRI 8610C GC-FID) (Skoog et al., 1997) after creating a $30 \mathrm{~mL}$ headspace with $\mathrm{N}_{2}$ in $70 \mathrm{~mL}$ glass serum bottles, following the procedure described by Abril and Iversen (2002). After creating the $\mathrm{N}_{2}$ headspace, samples were vigorously shaken for $20 \mathrm{~min}$ and were placed in a thermostatic bath overnight at $-1.6^{\circ} \mathrm{C}$. The following day, the samples were shaken again for $20 \mathrm{~min}$ before starting the $\mathrm{GC}$ analysis. $\mathrm{CH}_{4}: \mathrm{CO}_{2}: \mathrm{N}_{2}$ mixtures (Air Liquide, Belgium) of 1,10 and $30 \mathrm{ppm} \mathrm{CH}_{4}$ were used as standards. The concentrations were then computed using the $\mathrm{CH}_{4}$ solubility coefficient given by Yamamoto et al. (1976). The accuracy of the measurements was within $1 \%$.

We calculated the solubility of $\mathrm{CH}_{4}$ in seawater that is in equilibrium with the atmosphere, following Wiesenburg and Guinasso (1979). The ratio between the measured $\mathrm{CH}_{4}$ 
concentration in seawater and the calculated solubility in equilibrated seawater determines the supersaturation factor.

\section{3 $\quad \mathrm{CH}_{4}$ concentrations in bulk ice and brine}

We used the wet extraction method to extract $\mathrm{CH}_{4}$ from sea ice, as described in Raynaud et al. (1982) for continental ice. Briefly, $80 \mathrm{~g}$ of ice sample were put in a small container, using a $5 \mathrm{~cm}$ vertical resolution. The ice sample was then melted in the container under vacuum $\left(10^{-3}\right.$ torr $)$, using a "bain-marie". It was then slowly refrozen from the bottom, using an ethanol $(96 \%)$ bath that was cooled to $-80^{\circ} \mathrm{C}$ by the addition of liquid $\mathrm{N}_{2}$. After refreezing, the whole gas content (both dissolved and in the bubbles) was expelled into the headspace of the container. The expelled gas was then injected through a $22 \mathrm{~mL}$ packed column (Mole Sieve $5 \mathrm{~A}$ $80 / 100 ; 5 \mathrm{~m} \times 1 / 8^{\prime \prime}$ ) into a gas chromatograph (Trace GC) equipped with a flame ionization detector for $\mathrm{CH}_{4}$ measurement. The reproducibility of the measurement, based on triplicate analysis of five different standards, was $99.6 \%$.

The method described here above gives $\mathrm{CH}_{4}$ concentrations in bulk ice. Providing that there is no $\mathrm{CH}_{4}$ in the pure ice matrix (Weeks, 2010) and, hence, that the entire amount of $\mathrm{CH}_{4}$ (dissolved or in gas bubbles) is found within the ice pores (i.e. brine channels), $\mathrm{CH}_{4}$ concentration in bulk ice divided by the brine volume fraction (Cox and Weeks, 1983) gives the deduced $\mathrm{CH}_{4}$ concentration in brine.

Dissolved $\mathrm{CH}_{4}$ concentration in brine was also measured for brine samples collected using the sackhole technique (e.g. Gleitz et al., 1995; Papadimitriou et al., 2007). Sackholes (partial core holes) were drilled at different depths, ranging from 20 to $130 \mathrm{~cm}$. Brines, from adjacent brine channels and pockets, seeped into the sackholes and were collected after 10 to $60 \mathrm{~min}$ using a peristaltic pump (Cole Palmer, Masterflex ${ }^{\circledR}$ - Environmental Sampler). Each sackhole remained covered with a plastic lid to minimize mixing with the free atmosphere. Brines were collected in $70 \mathrm{~mL}$ glass serum bottles, filled to overflowing, poisoned with $100 \mu \mathrm{L}$ of saturated $\mathrm{HgCl}_{2}$ and sealed with butyl stoppers and aluminium caps. The measured $\mathrm{CH}_{4}$ concentration in brine is an integrated value of the $\mathrm{CH}_{4}$ in brine from all the ice layers above the sampling depth. Therefore, the vertical resolution is lower than that of the $\mathrm{CH}_{4}$ concentrations in brine that is deduced from the $\mathrm{CH}_{4}$ concentrations in bulk ice. It is also noteworthy that the relative contribution of the various depth levels is unknown and dependent on the brine volume changes with depth. However, it is of interest to compare the measured $\mathrm{CH}_{4}$ concentrations in brine with those deduced from the bulk ice values, as discussed later on.

For data interpretation, we calculated $\mathrm{CH}_{4}$ solubility in brine and in ice (i.e. potential $\mathrm{CH}_{4}$ concentration dissolved in brine and in bulk ice respectively). The solubility of $\mathrm{CH}_{4}$ in brine was calculated using the same temperature and salinitydependent solubility of Wiesenburg and Guinasso (1979) as for seawater. This is possible providing that the relationship of Wiesenburg and Guinasso (1979) is valid for the ranges of brine temperature and brine salinity. As for the conversion of $\mathrm{CH}_{4}$ concentrations in bulk ice into the deduced $\mathrm{CH}_{4}$ concentrations in brine, we simply multiplied the solubility of $\mathrm{CH}_{4}$ in brine by the brine volume fraction to get the solubility of $\mathrm{CH}_{4}$ in bulk ice. Brine salinity and brine volume (used in the calculations) were derived from the relationship of Cox and Weeks (1983). The ratio between the observed $\mathrm{CH}_{4}$ concentration in ice or brine to their respective calculated solubility determines the supersaturation factor.

In addition, we computed the standing stock of $\mathrm{CH}_{4}$, i.e. the total amount of $\mathrm{CH}_{4}$ within the ice cover. To do so, we integrated the concentrations of $\mathrm{CH}_{4}$ in bulk ice vertically to obtain the $\mathrm{CH}_{4}$ content per square metre of ice.

For further comparison with the literature, we also computed $\mathrm{CH}_{4}$ mixing ratios. They are usually obtained by dividing the number of moles of $\mathrm{CH}_{4}$ by the total gas content. However, since we did not measure the total gas content, we used the sum of measured atmospheric-dominant gases $\left(\mathrm{O}_{2}\right.$, $\mathrm{N}_{2}$ and Ar; data not shown) instead.

\section{Results}

\section{1 $\mathrm{CH}_{4}$ concentrations in ice}

$\mathrm{CH}_{4}$ concentrations in bulk ice ranged from $3.4 \mathrm{nmol} \mathrm{L}_{\text {ice }}^{-1}$ to $17.2 \mathrm{nmol} \mathrm{L}_{\text {ice }}^{-1}$. Mean $\mathrm{CH}_{4}$ concentration increased from BRW2 $\left(6.4 \mathrm{nmol} \mathrm{L}_{\text {ice }}^{-1}\right)$ to BRW7 $\left(7.8 \mathrm{nmol} \mathrm{L}_{\text {ice }}^{-1}\right)$ and decreased to $5.5 \mathrm{nmol} \mathrm{L}_{\text {ice }}^{-1}$ at BRW10. This evolution parallels that of the standing stocks of $\mathrm{CH}_{4}$, which increased from BRW2 (5070 to $5430 \mathrm{nmol} \mathrm{m}^{-2}$ ) to BRW7 $\left(9200 \mathrm{nmol} \mathrm{m}^{-2}\right)$, then decreased at BRW10 $\left(7580 \mathrm{nmol} \mathrm{m}^{-2}\right)$ (Fig. 2). For data interpretation, sea ice thickness is also shown in Fig. 2. It appears that the mean $\mathrm{CH}_{4}$ concentration and the standing stock increased as sea ice thickened from BRW2 to BRW7, but decreased at BRW10 despite the fact that sea ice was thicker there.

The individual profiles of $\mathrm{CH}_{4}$ concentrations in bulk ice (Fig. 3a) for each sampling event further highlight the contrasts between BRW10 and all the previous sampling events (BRW2 to BRW7): all the $\mathrm{CH}_{4}$ concentration profiles in ice from BRW2 to BRW7 can be divided into three main zones. The first one ranged from 0 to $25 \mathrm{~cm}$, where a peak of $\mathrm{CH}_{4}$ concentration was found at 15 to $25 \mathrm{~cm}$. $\mathrm{CH}_{4}$ concentration measurements made on a twin ice core of BRW2 (duplicate) show that spatial variability in the 15 to $25 \mathrm{~cm}$ layer could reach $60 \%$. The second zone was found in the ice interior and ranged from $25 \mathrm{~cm}$ to the upper limit of the permeable layers (shaded area), where $\mathrm{CH}_{4}$ concentrations were close to $5 \mathrm{nmol} \mathrm{L}-1$ ice . The third zone corresponds to the permeable layers where $\mathrm{CH}_{4}$ concentration increased again toward the sea ice bottom, with values ranging from 5 to $10 \mathrm{nmol} \mathrm{L}_{\text {ice }}^{-1}$. At BRW10, as the whole ice cover became permeable (shaded area at all depths), the whole profile flattened: the peak of 


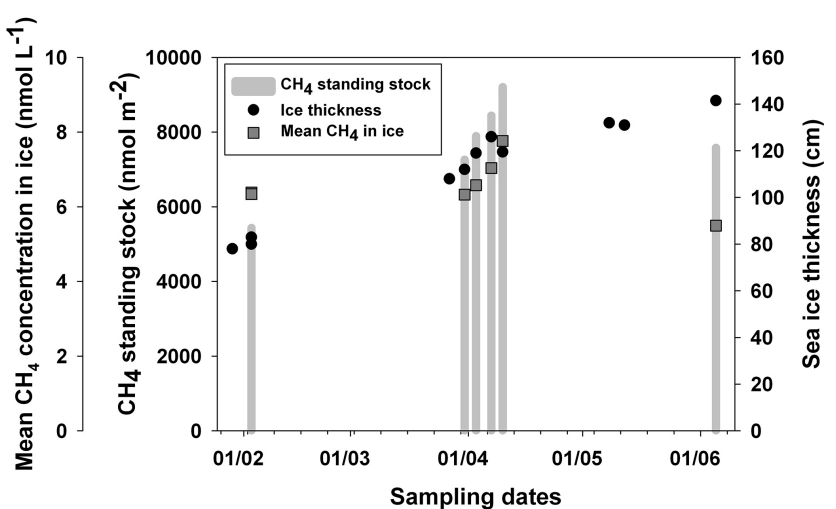

Figure 2. $\mathrm{CH}_{4}$ standing stock for selected samplings events (vertical bars, from left to right, BRW2, BRW4, BRW5, BRW6, BRW7 and BRW10) in parallel with mean $\mathrm{CH}_{4}$ concentration in sea ice and sea ice thickness.

$\mathrm{CH}_{4}$ concentration around 15 to $25 \mathrm{~cm}$ disappeared, the ice interior still has a baseline at $5 \mathrm{nmol} \mathrm{L}_{\text {ice }}^{-1}$ and the increase of $\mathrm{CH}_{4}$ concentration at the bottom was less obvious than in the previous sampling events.

Beside the strong vertical variation, $\mathrm{CH}_{4}$ concentrations in bulk ice were always higher than the solubility values in surface seawater that would have been in equilibrium with the atmosphere $\left(3.8 \mathrm{nmol} \mathrm{L}_{\mathrm{sw}}^{-1}\right)$ and the theoretical solubility in ice at all depths (Fig. $3 \mathrm{a}-$ white dots). $\mathrm{CH}_{4}$ concentrations in bulk ice were on average 1.8 times higher than that in surface seawater and 75 times higher than the theoretical solubility in ice. The highest supersaturation factor reached 396 and was measured in BRW6, at a depth of 20 to $25 \mathrm{~cm}$. Again, BRW10 differed from all the other sampling events, with a lower supersaturation factor (mean supersaturation and standard deviation were $11 \pm 4$ versus $86 \pm 68$ for BRW2 to BRW7).

The $\mathrm{CH}_{4}$ mixing ratio (not shown) was also calculated for BRW2, BRW4, BRW7 and BRW10. It ranged from 5.8 to $105.3 \mathrm{ppmV}$. The maximum mixing ratio was found in BRW4, at a depth of 15 to $20 \mathrm{~cm}$; this is 3.6 times higher than the mean mixing ratio of $29 \mathrm{ppmV}$.

To summarize, BRW10 differed from all the other samplings events by its lower mean $\mathrm{CH}_{4}$ concentration and its flatter $\mathrm{CH}_{4}$ concentration profiles. Although all the ice samples were supersaturated relative to surface seawater, larger supersaturations were observed from BRW2 to BRW7 (less permeable ice cores) compared to BRW10 (entirely permeable ice core), especially at a depth of 15 to $25 \mathrm{~cm}$ where both $\mathrm{CH}_{4}$ concentrations and $\mathrm{CH}_{4}$ mixing ratios were found to be the highest.

\section{2 $\mathrm{CH}_{4}$ concentrations in brine}

Deduced $\mathrm{CH}_{4}$ concentrations in brine (using $\mathrm{CH}_{4}$ concentrations in ice) ranged from $13.2 \mathrm{nmol} \mathrm{L}_{\text {brine }}^{-1}$ to
$677.7 \mathrm{nmol} \mathrm{L}$ brine. These are thus much higher than the range of $\mathrm{CH}_{4}$ concentrations measured in brine sackholes (10.0 to $36.2 \mathrm{nmol} \mathrm{L}_{\text {brine }}^{-1}$ ) (Fig. 3 - triangles) and in seawater (25.9 and $116.4 \mathrm{nmol} \mathrm{L}_{\mathrm{sw}}^{-1}$ ).

The evolution of $\mathrm{CH}_{4}$ concentrations in brine across seasons was rather similar to that of $\mathrm{CH}_{4}$ concentrations in bulk ice, except in the bottom layers. Indeed, from BRW2 to BRW7, high $\mathrm{CH}_{4}$ concentrations in brine were also observed at a depth of 15 to $20 \mathrm{~cm}$; but from that level, $\mathrm{CH}_{4}$ concentration in brine decreased and reached the lowest values at the sea ice bottom, where it is similar to observed $\mathrm{CH}_{4}$ values in seawater. There was thus no increase of $\mathrm{CH}_{4}$ concentration in brine at the sea ice bottom as observed in the $\mathrm{CH}_{4}$ concentrations in bulk ice. The profile of $\mathrm{CH}_{4}$ concentrations in brine flattened at BRW10, with values ranging between 13.2 and $87.0 \mathrm{nmol} \mathrm{L}_{\text {brine }}^{-1}$, which were less variable and much closer to both the solubility values in brine and the actual measured $\mathrm{CH}_{4}$ concentrations in brine than the ranges of values in the previous sampling events $\left(35.6 \mathrm{nmol} \mathrm{L}_{\text {brine }}^{-1}\right.$ and $677.7 \mathrm{nmol} \mathrm{L}_{\text {brine }}^{-1}$ ). The minimum $\mathrm{CH}_{4}$ concentration in brine was calculated at $12.5 \mathrm{~cm}$. Temperature data were missing at the very surface, so that we could not compute $\mathrm{CH}_{4}$ concentrations in brine above $12.5 \mathrm{~cm}$.

\section{3 $\mathrm{CH}_{4}$ concentrations in seawater}

Measured $\mathrm{CH}_{4}$ concentrations in seawater ranged from 25.9 to $116.4 \mathrm{nmol} \mathrm{L}_{\mathrm{sw}}^{-1}$ (Fig. 3c). This is 7 to 31 times higher than seawater in equilibrium with the atmosphere $\left(3.8 \mathrm{nmol} \mathrm{L}^{-1}\right.$ for a salinity of 35 at $0^{\circ} \mathrm{C}$ ) (Wiesenburg and Guinasso, 1979).

Measurements of $\mathrm{CH}_{4}$ concentrations in seawater were homogenous in time from BRW2 to BRW7, with a mean value and standard deviation of $42.0 \pm 2.4 \mathrm{nmol} \mathrm{L}-1$ for BRW2 and $37.5 \pm 6 \mathrm{nmol} \mathrm{L}_{\mathrm{sW}}^{-1}$ for BRW4 to BRW7. They then increased at all depths at BRW10 and reached a mean value and standard deviation of $77.4 \pm 27.8 \mathrm{nmol} \mathrm{L}_{\mathrm{sw}}^{-1}$.

\section{Discussion}

The present paper aims at understanding the physical controls on the $\mathrm{CH}_{4}$ concentrations in sea ice. Discussing the physical controls only makes sense if the variations of $\mathrm{CH}_{4}$ concentration due to biological activity are negligible compared to those due to physical processes. Therefore, we will first assess the importance of biological activity on the variation of $\mathrm{CH}_{4}$ concentrations in sea ice and brine (Sect. 4.1) before discussing the physical controls (Sect. 4.2).

\subsection{Impact of biological activity on $\mathrm{CH}_{4}$ concentrations}

To assess the impact of biological activity on $\mathrm{CH}_{4}$ concentrations, we recalculated the standing stocks of BRW4 to BRW7 (Fig. 3), by considering every $5 \mathrm{~cm}$ ice sample in the 25 to $80 \mathrm{~cm}$ depth layers. These choices are motivated by the 

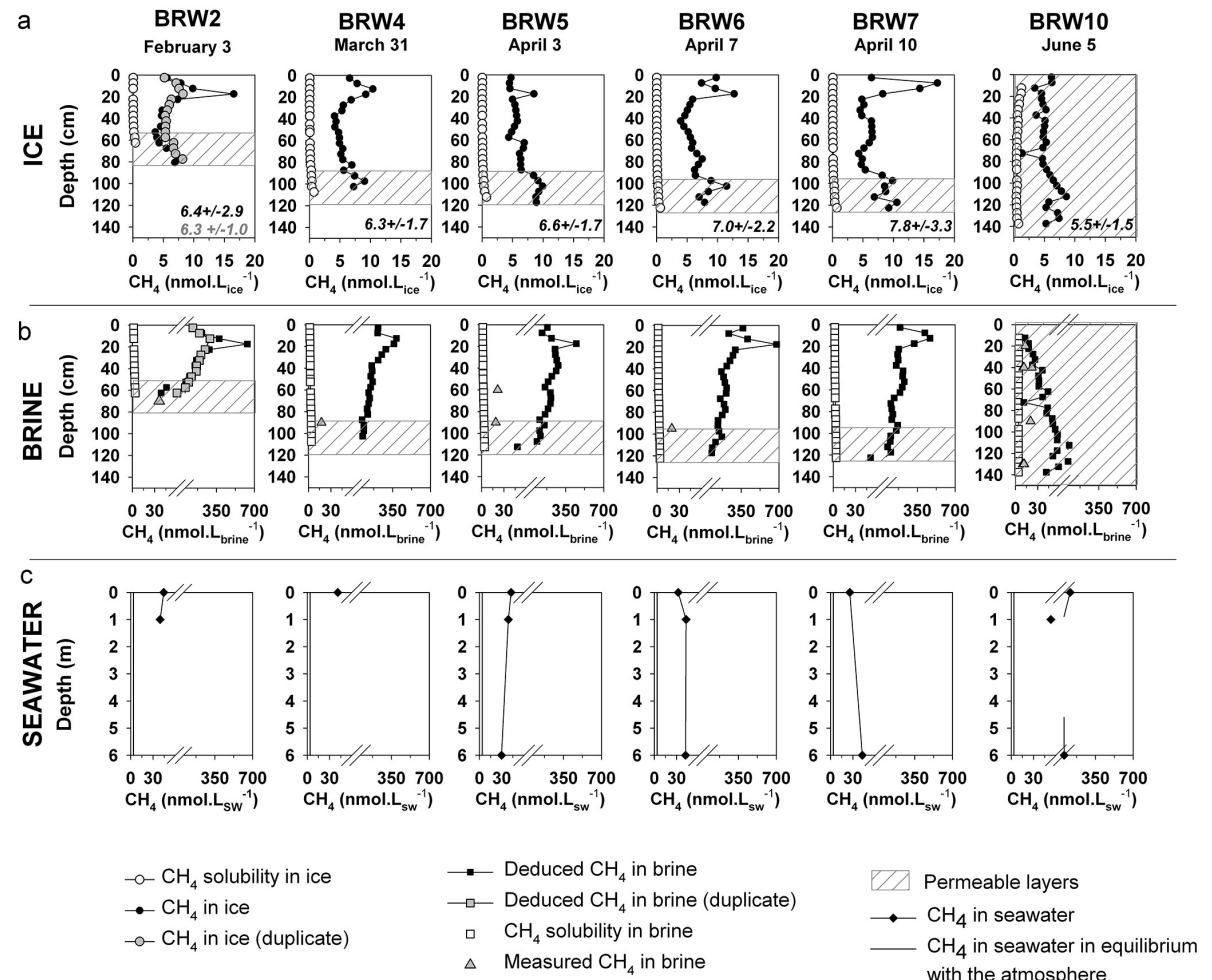

Figure 3. Evolution of $\mathrm{CH}_{4}$ concentration in (a) bulk ice, (b) brine and (c) seawater (black dots, squares and diamonds respectively), compared to $\mathrm{CH}_{4}$ solubility in ice, brine and seawater that is in equilibrium with the atmosphere (white dots, white squares and black straight lines respectively). Grey dots and grey squares are measurements made on duplicate samples of BRW2. Grey triangles in (b) are $\mathrm{CH}_{4}$ measurements in brine sackholes. The break in the $x$ axes of (b) and (c) is set at $60 \mathrm{nmol}$ L. Dashed areas are permeable layers (i.e. layers with a brine volume fraction above $5 \%$ ).

following reasons: first, we suggest focusing on the standing stocks of the impermeable layers (i.e. layers that have a brine volume fraction below $5 \%$ (Golden et al., 1998); layers above the shaded areas on Fig. 3a, b). These layers are considered as a closed system in terms of brine dynamics and are therefore suitable for assessing biological transformation of $\mathrm{CH}_{4}$. Second, we felt it appropriate to ignore the upper layer $(0$ to $25 \mathrm{~cm})$, since spatial variability could be important in these layers (up to $60 \%$ the 15 to $25 \mathrm{~cm}$ depth layer) as shown in Fig. 3a - BRW2. Third, we only focused on the sampling events that were collected at short time intervals (three or four days), i.e. BRW4 to BRW7 rather than BRW2 to BRW4 (56 days). This is mainly due to the similar physical properties of the ice cores collected at short time intervals (i.e. in terms of ice core length, ice temperature and ice salinity profiles).

Deduced $\mathrm{CH}_{4}$ standing stocks in the $5 \mathrm{~cm}$ ice samples (in the 25 to $80 \mathrm{~cm}$ ice layer, from BRW4 to BRW7) varied between 198 and $375 \mathrm{nmol} \mathrm{m}^{-2}$, with a mean and standard deviation of $271 \pm 41 \mathrm{~mol} \mathrm{~m}^{-2}$. We performed an ANalysis Of VAriance (ANOVA) test on these standing stocks $(n=44)$ and differences between the samplings were not significant enough to exclude the possibility of random sampling variability.

In addition, we plotted chlorophyll $a$ concentrations against $\mathrm{CH}_{4}$ concentrations in bulk ice and phosphate concentrations against $\mathrm{CH}_{4}$ concentrations in bulk ice to investigate potential in situ production of $\mathrm{CH}_{4}$ in both permeable and impermeable ice layers (see Appendix A). The rationale is that previous studies have shown a strong correlation between these variables (Damm et al., 2008, 2010) where $\mathrm{CH}_{4}$ production was found to occur. As there is no obvious correlation between the presented variables (see Appendix A), we surmise that the pathway of $\mathrm{CH}_{4}$ production that was observed in Damm et al. $(2008,2010)$ may not have occurred in the present study.

Furthermore, the turnover time for $\mathrm{CH}_{4}$ oxidation in the Arctic Ocean exceeds 1.5 years (Griffiths et al., 1982, and Valentine et al., 2001), which is much longer than the lifetime of first-year landfast ice. If we assumed that the turnover time is similar in landfast sea ice, then we would not expect to find major $\mathrm{CH}_{4}$ oxidation in our ice samples.

Because $\mathrm{CH}_{4}$ production is unlikely in sea ice and $\mathrm{CH}_{4} \mathrm{Ox}-$ idation may be slow, we conclude that biological transformation of $\mathrm{CH}_{4}$ is negligible in comparison with the amount of 




Figure 4. Schematic figure of $\mathrm{CH}_{4}$ incorporation and release in sea ice. Sizes are intentionally disproportionate to highlight processes better. The area above the dotted line represents the impermeable layers. The small filled and empty circles represent $\mathrm{CH}_{4}$ in gas bubbles and in dissolved state respectively. Upward grey arrows indicate the upward transport of gas bubbles due to their buoyancy, while downward blue arrows indicate the removal of dissolved gas through brine drainage. Large black circles zoom in on particular processes described in the text (Sect. 4.2): gas exchanges at the beginning of ice growth, gas accumulation predominantly under the impermeable layers and gas bubble escape during ice decay. Dark blue, light blue and cyan strokes in ice represent brine channels with high, moderate or low salinity respectively.

$\mathrm{CH}_{4}$ that was physically incorporated in the impermeable ice layers; this is consistent with the findings derived from the standing stocks. Therefore, the discussion below will mainly focus on the physical processes that regulate $\mathrm{CH}_{4}$ concentrations in sea ice.

\subsection{Impact of physical processes on $\mathrm{CH}_{4}$ concentrations}

\subsubsection{Range of $\mathrm{CH}_{4}$ concentrations in sea ice and seawater, comparison with the literature}

Our $\mathrm{CH}_{4}$ concentrations in sea ice $\left(3.4-17.2 \mathrm{nmol} \mathrm{L}_{\text {ice }}^{-1}\right)$ were slightly lower than those of Lorenson and Kvenvolden (1995) ( 15 to $40 \mathrm{nmol} \mathrm{L}-1$ ice). The deduced mixing ratios (5.8 to $105.3 \mathrm{ppmV}$ ) were, however, much lower than the $11000 \mathrm{ppmV}$ of Shakhova et al. (2010). We attribute the observed differences to (1) the $\mathrm{CH}_{4}$ concentrations in seawater and (2) ebullition processes (i.e. the seepage of $\mathrm{CH}_{4}$ bubbles from the seafloor and their rising through the water column).

First, our $\mathrm{CH}_{4}$ concentrations in seawater (25.9 and $116.4 \mathrm{nmol} \mathrm{L}_{\mathrm{sw}}^{-1}$ ) are consistent with those reported in northern Alaska (10.7 to $111.8 \mathrm{nmol} \mathrm{L}_{\mathrm{sw}}^{-1}$; Kvenvolden et al., 1993) and shallow shelf areas with $\mathrm{CH}_{4}$ release from sediment and/or destabilized gas hydrate $\left(2.1\right.$ to $154 \mathrm{nmol} \mathrm{L}_{\mathrm{sw}}^{-1}$; Shakhova et al., 2005), but are much lower than the measurements reported by Shakhova et al. (2010) (1.8 to $2880 \mathrm{nmol} \mathrm{L}_{\mathrm{sw}}^{-1}$ ). The differences in $\mathrm{CH}_{4}$ concentrations in seawater lead to contrasting $\mathrm{CH}_{4}$ supersaturations $(700 \%$ and $3100 \%$ in the present study versus $100 \%$ to $160000 \%$ in
Shakhova et al., 2010). Assuming similar incorporation rates in both studies, lower $\mathrm{CH}_{4}$ supersaturation in seawater leads to lower $\mathrm{CH}_{4}$ incorporated into sea ice and hence a lower $\mathrm{CH}_{4}$ mixing ratio in sea ice.

Second, ebullition is a process associated with rapid bubble ascension, limiting gas equilibration with the surrounding water mass (Keller and Stallard, 1994). Therefore, in shallow locations, $\mathrm{CH}_{4}$ bubbles released from the seafloor could reach the seawater surface (Keller and Stallard, 1994; McGinnis et al., 2006). We believe that ebullition could increase $\mathrm{CH}_{4}$ at the sea-ice-water interface and lead to larger $\mathrm{CH}_{4}$ incorporation into sea ice than if the ebullition was absent. Ebullitions were clearly observed in the Siberian Arctic Shelf (Shakhova et al., 2010) and, in that particular case, centimetre-sized bubbles were found within the ice (Shakhova et al., 2010). Since we did not find any literature reporting ebullition processes at Barrow and since our ice cores generally showed millimetre-sized bubbles (Zhou et al., 2013), we believe that ebullition processes were much less important in our study than in Shakhova et al. (2010).

\subsubsection{Mechanisms responsible for the evolution of the vertical profiles of $\mathrm{CH}_{4}$ concentrations in bulk ice and brine during ice growth}

Although the $\mathrm{CH}_{4}$ source was seawater, $\mathrm{CH}_{4}$ concentrations in bulk ice from BRW2 to BRW7 did not show a C-shaped profile, as would salinity for growing sea ice (Petrich and Eicken, 2010). For instance, instead of a surface maximum for salt, we observed a subsurface maximum for $\mathrm{CH}_{4}$. As discussed below, we propose three abiotic mechanisms to explain the salient features of the vertical profiles of $\mathrm{CH}_{4}$ concentration in Barrow bulk ice: (1) gas escape during the initial ice growth phase in the surface layer, (2) predominant gas accumulation in the subsurface and (3) brine volume fraction effect for the bottom layer.

We assume that $\mathrm{CH}_{4}$, similarly to $\mathrm{CO}_{2}$, could escape from the ice to the atmosphere at the beginning of the ice growth (Geilfus et al., 2013; Nomura et al., 2006) (Fig. 4). In addition, once sea ice is consolidated, changes in temperature and in the volume of brine pockets are likely to fracture the ice, causing the expulsion of brines (Notz and Worster, 2009) and air bubbles (Untersteiner, 1968) at the ice surface. These two processes could explain the decrease of $\mathrm{CH}_{4}$ concentrations in bulk ice right at the surface of sea ice (Fig. 3).

Predominant gas accumulation during ice growth has been described for argon (Ar) in Zhou et al. (2013): in addition to brine concentration, temperature and salinity changes in brine at sea ice formation lead to a sharp decrease of $\mathrm{CH}_{4}$ solubility that favours bubble nucleation in sea ice. Once formed, the bubbles migrate upward due to their buoyancy. They are trapped under the impermeable surface layer, leading to gas accumulation (Fig. 4). Such a process is supported by two characteristics: the presence of bubbles and the occurrence of large supersaturation levels (compared to the rest of 


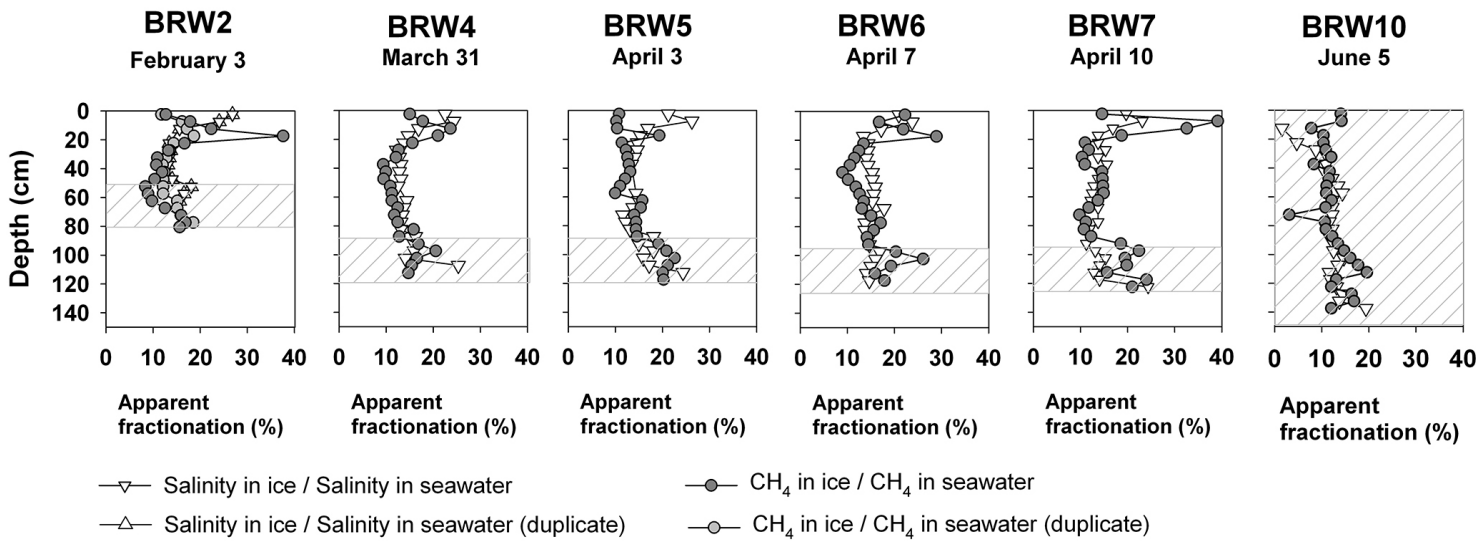

Figure 5. Comparison between the apparent fractionation of salinity in ice (the ratio between ice salinity and seawater salinity (32)) and the apparent fractionation of $\mathrm{CH}_{4}$ (the ratio between $\mathrm{CH}_{4}$ in ice and $\mathrm{CH}_{4}$ in seawater $\left(44 \mathrm{nmol} \mathrm{L}-1\right.$ )). The seawater salinity and $\mathrm{CH}_{4}$ in seawater that are chosen as references were the values obtained from BRW2. Dashed areas are permeable layers (i.e. layers with a brine volume fraction above $5 \%$ ).

the ice core). The presence of bubbles was observed in thin sections by Zhou et al. (2013) and is also consistent with the large difference between the deduced $\mathrm{CH}_{4}$ in brine (which includes both $\mathrm{CH}_{4}$ in bubbles and $\mathrm{CH}_{4}$ that is dissolved in brine) (Fig. 3b, squares) and the actual measurements of $\mathrm{CH}_{4}$ in brine (only $\mathrm{CH}_{4}$ that is dissolved in brine) (Fig. 3, triangles). Moreover, the largest $\mathrm{CH}_{4}$ supersaturations relative to $\mathrm{CH}_{4}$ solubility in ice were always found at a depth of 15 to $25 \mathrm{~cm}$, which corresponds to the ice depth where Zhou et al. (2013) have observed bubble accumulation and Ar supersaturation up to $2900 \%$. Therefore, the mechanism of predominant gas accumulation suggested for Ar may be relevant for $\mathrm{CH}_{4}$ as well. Larger $\mathrm{CH}_{4}$ supersaturation as compared to Ar supersaturation is likely due to the difference in $\mathrm{CH}_{4}$ and Ar solubility; $\mathrm{CH}_{4}$, which is less soluble than Ar, would be more affected by temperature and salinity changes. It is also noteworthy that this process of bubble formation in sea ice led to large spatial variability as witnessed by the duplicate of BRW2, which showed up to $60 \%$ of $\mathrm{CH}_{4}$ variation at a depth of 15 to $25 \mathrm{~cm}$.

As the freezing front progresses, the temperature gradient in the permeable layer reduces; bubble nucleation due to solubility decrease is less efficient. As a consequence, $\mathrm{CH}_{4}$ accumulates less and $\mathrm{CH}_{4}$ concentration in brine decreases towards the bottom. Such a decrease is however not observed for $\mathrm{CH}_{4}$ concentration in bulk ice. We attribute this to the brine volume fraction effect: a larger brine volume may contain a larger amount of $\mathrm{CH}_{4}$ molecules, which induces higher $\mathrm{CH}_{4}$ concentrations in bulk ice. The fact that $\mathrm{CH}_{4}$ in brine did not show an increase at the bottom of the ice supports this suggestion.

An alternative explanation for the predominant gas accumulation due to solubility changes would be that of a direct bubble incorporation after a sudden but intense release of $\mathrm{CH}_{4}$ bubbles from the sediment to the ice bottom. $\mathrm{CH}_{4}$ release from sediment is possible since our $\mathrm{CH}_{4}$ concentrations in seawater are consistent with those found in areas where $\mathrm{CH}_{4}$ release from sediment and/or gas hydrate destabilization likely occurs (see Sect. 4.2.1). However, this process does not explain the slow decrease of $\mathrm{CH}_{4}$ concentration in brine from a depth of 15 to $25 \mathrm{~cm}$ to the sea ice bottom (Fig. 3b), and we may also wonder why the ebullition only occurred once during the whole sampling period.

The contribution of in situ bubble formation in the retention of $\mathrm{CH}_{4}$ in sea ice is assessed in Fig. 5. We calculated the ratio between $\mathrm{CH}_{4}$ in ice and the $\mathrm{CH}_{4}$ in seawater at BRW2 $(44 \mathrm{nmol} \mathrm{L}-1)$ and the ratio between brine salinity and the salinity of seawater at BRW2 (32) at each ice depth for all the sampling events. The $\mathrm{CH}_{4}$ in seawater and the salinity of seawater of BRW2 were chosen as references for the sake of consistency with Zhou et al. (2013). Similar apparent fractionation means that $\mathrm{CH}_{4}$ is retained (incorporated and transported) in sea ice in the same way to salt, while a difference in the apparent fractionation means a difference in their retention processes.

Four main observations can be made with regard to Fig. 5. First, the apparent fractionation averaged $15 \%$ but never reached $100 \%$. This is due to the rejection of impurities during sea ice formation (Weeks, 2010). Our study therefore suggests that sea ice rejects about $85 \%$ of its impurities, but retains $15 \%$ of them. This is in agreement with Petrich and Eicken (2010), who suggested that sea ice brine allows a retention of 10 to $40 \%$ of seawater ions in the ice. Second, the highest apparent fractionation of $\mathrm{CH}_{4}$ (up to $39 \%$ ) was observed at a depth of 15 to $25 \mathrm{~cm}$; in that layer, the retention of $\mathrm{CH}_{4}$ could be higher than that of salt by a factor of 2 . This supports the previous suggestion about predominant gas accumulation: the presence of gas bubbles allows higher retention of $\mathrm{CH}_{4}$ than salt. Third, the apparent fractionation of $\mathrm{CH}_{4}$ was lower than that of salt at the surface 
of all the sampling events, except at BRW10. That lower apparent fractionation may be related to the large permeability of the ice during its formation and/or the formation of some cracks at the ice surface (during the cold period), which have allowed gas to escape from sea ice to the atmosphere, as explained earlier in this section. The lower $\mathrm{CH}_{4}$ concentrations in bulk ice at these sampling events (Fig. 3a) tends to support the conjecture of gas escape. Fourth, below the top layer of about $25 \mathrm{~cm}$ of ice, both $\mathrm{CH}_{4}$ and salt enrichment values are similar, indicating that, in these ice layers, $\mathrm{CH}_{4}$ was mainly incorporated in the dissolved state in the same way as salt.

\subsubsection{Sea ice permeability controls $\mathrm{CH}_{4}$ concentrations in bulk ice and brine during sea ice decay}

At BRW10, both $\mathrm{CH}_{4}$ concentrations in bulk ice and deduced $\mathrm{CH}_{4}$ concentrations in brine decreased and became less variable than the previous samplings (BRW2 to BRW7). In addition, $\mathrm{CH}_{4}$ standing stocks decreased by ca. $1600 \mathrm{nmol} \mathrm{m}^{-2}$ from BRW7 to BRW10, and the deduced $\mathrm{CH}_{4}$ concentrations in brine approached the measured concentrations. These measurements suggest that there is an enhanced gas transport through the ice and that gas bubbles have escaped from sea ice to the atmosphere. Gas escape was possible given that sea ice was permeable at all depths (Fig. 3a, b, shaded area). Concomitant Ar bubble escape was suggested in Zhou et al. (2013). However, in contrast to Ar that was then at saturation, $\mathrm{CH}_{4}$ was still supersaturated compared to the solubility in brine. This could be related to a slow exchange between the atmosphere, brine and the supersaturated seawater through diffusion.

$\mathrm{CH}_{4}$ concentrations in brine at BRW10 (13.2 to $87.0 \mathrm{nmol} \mathrm{L}-1$ brine $)$ were lower than the $\mathrm{CH}_{4}$ concentration at the ice/water interface $\left(116.4 \mathrm{nmol} \mathrm{L}_{\mathrm{sw}}^{-1}\right)$, but higher than the theoretical $\mathrm{CH}_{4}$ solubility in surface seawater that is in equilibrium with the atmosphere $\left(3.8 \mathrm{nmol} \mathrm{L}_{\mathrm{sw}}^{-1}\right)$. Although the $\mathrm{CH}_{4}$ concentrations in brine right at the surface $(0-12.5 \mathrm{~cm})$ could not be retrieved, we can hypothesize that the gradient of $\mathrm{CH}_{4}$ concentrations between the ice/seawater interface and the ice surface led to $\mathrm{CH}_{4}$ diffusion from the ice/seawater interface to the ice surface and therefore maintained $\mathrm{CH}_{4}$ supersaturation in ice after gas bubble escape. Since the source of $\mathrm{CH}_{4}$ came from supersaturated seawater, $\mathrm{CH}_{4}$ concentrations in brine were slightly higher at the sea ice bottom than at the top.

\section{Conclusions and perspectives}

We reported on the evolution of $\mathrm{CH}_{4}$ concentrations in landfast sea ice, brine and under-ice water from February through June 2009 at Barrow (Alaska). Our $\mathrm{CH}_{4}$ concentrations in sea ice in seawater are consistent with records from the area with $\mathrm{CH}_{4}$ release from sediment and gas hydrate destabilization (Kvenvolden et al., 1993; Lorenson and Kvenvolden, 1995; Shakhova et al., 2010).

We suggest that brine concentration and strong solubility decrease triggered gas bubble formation, which favoured $\mathrm{CH}_{4}$ accumulation in ice. As a result, $\mathrm{CH}_{4}$ retention in the ice was twice as efficient as that of salt. However, as summarized in Fig. 4, gas exchange likely took place during initial ice growth between sea ice and the atmosphere, and the formation of cracks could also lead to a decrease of $\mathrm{CH}_{4}$ right at the surface of the ice. Also, as sea ice thickened, temperature and brine salinity gradient were no longer sufficient to trigger bubble nucleation, and $\mathrm{CH}_{4}$ was then trapped in the dissolved state in the same was as salt. The subsequent evolution of $\mathrm{CH}_{4}$ concentrations in sea ice layers mainly depended on physical processes, as chlorophyll $a$ and phosphate concentrations did not support in situ $\mathrm{CH}_{4}$ production and as $\mathrm{CH}_{4}$ oxidation was likely insignificant. Abrupt changes in $\mathrm{CH}_{4}$ concentrations in sea ice occurred when sea ice became permeable; these were associated with the release of gas bubbles to the atmosphere. Therefore, the main role of our landfast sea ice in the exchange of $\mathrm{CH}_{4}$ from seawater to the atmosphere was its control of the amount of $\mathrm{CH}_{4}$ that it is able to store in its impermeable layers and the duration of such storage.

Although gas incorporation and sea ice permeability were two dominant factors driving $\mathrm{CH}_{4}$ concentrations in sea ice in our study site, the magnitude of these processes may be different in other polar seas. Indeed, the contribution of the ebullition fluxes of $\mathrm{CH}_{4}$ from sediment to the concentration of $\mathrm{CH}_{4}$ in bulk ice, the transport of $\mathrm{CH}_{4}$ through the ice and the significance of physical and biological controls on $\mathrm{CH}_{4}$ dynamics rely on the nature of the sediment, the water depth, the physical parameters of the ice and biological activity within the ice, which may vary depending on the location.

In the case of a higher mix of physical and biological controls on $\mathrm{CH}_{4}$ concentrations in bulk ice, we would recommend measuring: (1) the carbon and hydrogen isotopes of $\mathrm{CH}_{4}$ in sea ice, as isotopic fractionation is highly sensitive to biological processes; and (2) the same isotopes in the sources (e.g. organic matter). Indeed, previous studies have suggested that the carbon isotopic values of biogenic $\mathrm{CH}_{4}$ within anoxic sediments may be as negative as $-110 \%$ o (Whiticar, 1999) in comparison to those resulting from $\mathrm{CH}_{4}$ oxidation ( -10 to $-24 \%$; Damm et al., 2008; Schubert et al., 2011), but few of them have considered that the measured isotopic values in the sediment or in seawater also depend on the isotopic composition of the sources. 
Appendix A: Relationships between chlorophyll $a$ and

$\mathrm{CH}_{4}$ concentrations and between phosphate and $\mathrm{CH}_{4}$ concentrations in sea ice
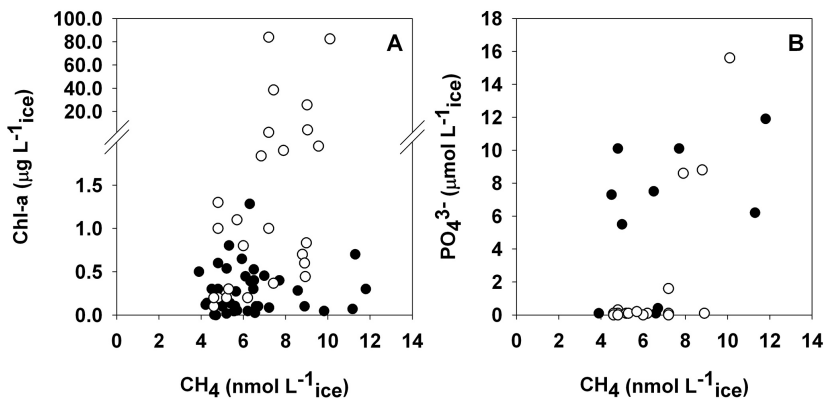

Figure A1. Relationships between $(\mathbf{A})$ chlorophyll $a(\mathrm{Chl} a)$ and methane $\left(\mathrm{CH}_{4}\right)$ concentrations, and $(\mathbf{B})$ phosphate $\left(\mathrm{PO}_{4}^{3-}\right)$ and $\mathrm{CH}_{4}$ concentrations in sea ice. Open and closed circles indicate respectively permeable and impermeable ice layers (i.e. a brine volume fraction above or below 5\%). Chl $a$ and $\mathrm{PO}_{4}^{3-}$ data are from Zhou et al. (2013); Chl $a$ data were available for all the sampling events that are presented here, while $\mathrm{PO}_{4}^{3-}$ data were only available for BRW2, BRW7 and BRW10. 
Acknowledgements. The authors would like to thank Hajo Eicken, the rest of the sea ice group of the Geophysical Institute of the University of Alaska Fairbanks, Tim Papakyriakou, Bernard Heinesch, Michel Yernaux, Frédéric Brabant, Thomas Goossens, Noémie Carnat and Rodd Laing for their help during fieldwork. We are indebted to the Barrow Arctic Science Consortium and the North Slope Borough for their logistical support. We also thank Saïda El Amri and Arnaud Rottier for their efficient help with laboratory work, Ceri Middleton for language help and Célia Sapart and Neige Egmont for their comments. Our gratitude also goes to the three anonymous reviewers as their comments have greatly improved the quality of the manuscript. This research was supported by the F.R.S-FNRS (contract 2.4584.09), the National Science Foundation (project OPP-0632398 (SIZONet)), the University of Alaska Fairbanks and the Belgian Science Policy (contract SD/CA/03A), the NCE ArcticNet and National Science and Engineering Research Council (NSERC). N.-X. Geilfus received a PhD grant from F.R.S.-FRIA and acknowledges the Canada Excellence Research Chair Program and the Arctic Science Partnership (ASP). J. Zhou is a research fellow of F.R.S.-FNRS, and B. Delille is a research associate of F.R.S.-FNRS. This is MARE contribution no. 265.

Edited by: L. Kaleschke

\section{References}

Abril, G. and Iversen, N.: Methane dynamics in a shallow non-tidal estuary (Randers Fjord, Denmark), Mar. Ecol.-Prog. Ser., 230, 171-181, 2002.

Bange, H. W., Bartell, U. H., Rapsomanikis, S., and Andreae, M. O.: Methane in the Baltic and North Seas and a Reassessment of the Marine Emissions of Methane, Global Biogeochem. Cy., 8, 465-480, 1994.

Bates, T. S., Kelly, K. C., Johnson, J. E., and Gammon, R. H.: A reevaluation of the open ocean source of methane to the atmosphere, J. Geophys. Res., 101, 6953-6961, 1996.

Borges, A. V. and Abril, G.: 5.04 - Carbon Dioxide and Methane Dynamics in Estuaries, in: Treatise on Estuarine and Coastal Science, Editors-in-Chief: Eric, W. and Donald, M. (Eds.), Academic Press, Waltham, 2011.

Cox, G. F. N. and Weeks, W. F.: Equations for determining the gas and brine volumes in sea-ice samples, J. Glaciol., 29, 306-316, 1983.

Damm, E., Schauer, U., Rudels, B., and Haas, C.: Excess of bottomreleased methane in an Arctic shelf sea polynya in winter, Cont. Shelf Res., 27, 1692-1701, 2007.

Damm, E., Kiene, R. P., Schwarz, J., Falck, E., and Dieckmann, G.: Methane cycling in Arctic shelf water and its relationship with phytoplankton biomass and DMSP, Mar Chem., 109, 4559, 2008.

Damm, E., Helmke, E., Thoms, S., Schauer, U., Nöthig, E., Bakker, K., and Kiene, R. P.: Methane production in aerobic oligotrophic surface water in the central Arctic Ocean, Biogeosciences, 7, 1099-1108, doi:10.5194/bg-7-1099-2010, 2010.

Florez-Leiva, L., Damm, E., and Farías, L.: Methane production induced by dimethylsulfide in surface water of an upwelling ecosystem, Prog. Oceanogr., 112-113, 38-48, doi:10.1016/j.pocean.2013.03.005, 2013.
Geilfus, N. X., Carnat, G., Papakyriakou, T., Tison, J. L., Else, B., Thomas, H., Shadwick, E., and Delille, B.: Dynamics of $p \mathrm{CO}_{2}$ and related air-ice $\mathrm{CO}_{2}$ fluxes in the Arctic coastal zone (Amundsen Gulf, Beaufort Sea), J. Geophys. Res.-Oceans, 117, C00G10, doi:10.1029/2011JC007118, 2012.

Geilfus, N. X., Carnat, G., Dieckmann, G. S., Halden, N., Nehrke, G., Papakyriakou, T., Tison, J. L., and Delille, B.: First estimates of the contribution of $\mathrm{CaCO}_{3}$ precipitation to the release of $\mathrm{CO}_{2}$ to the atmosphere during young sea ice growth, J. Geophys. Res.Oceans, 118, 244-255, 2013.

Gleitz, M., v. d. Loeff, M. R., Thomas, D. N., Dieckmann, G. S., and Millero, F. J.: Comparison of summer and winter in organic carbon, oxygen and nutrient concentrations in Antarctic sea ice brine, Mar. Chem., 51, 81-91, 1995.

Golden, K. M., Ackley, S. F., and Lytle, V. I.: The percolation phase transition in sea ice, Science, 282, 2238-2241, 1998.

Griffiths, R. P., Caldwell, B. A., Cline, J. D., Broich, W. A., and Morita, R. Y.: Field observations of methane concentrations and oxidation rates in the southeastern Bering Sea, Appl. Environ. Microb., 44, 435-446, 1982.

He, X., Sun, L., Xie, Z., Huang, W., Long, N., Li, Z., and Xing, G.: Sea ice in the Arctic Ocean: Role of shielding and consumption of methane, Atmos. Environ., 67, 8-13, 2013.

Judd, A. G.: Natural seabed gas seeps as sources of atmospheric methane, Environ. Geol., 46, 988-996, 2004.

Karl, D. M., Beversdorf, L., Bjorkman, K. M., Church, M. J., Martinez, A., and DeLong, E. F.: Aerobic production of methane in the sea, Nat. Geosci., 1, 473-478, 2008.

Keller, M. and Stallard, R. F.: Methane emission by bubbling from Gatun Lake, Panama, J. Geophys. Res., 99, 8307-8319, 1994.

Kirschke, S., Bousquet, P., Ciais, P., Saunois, M., Canadell, J. G., Dlugokencky, E. J., Bergamaschi, P., Bergmann, D., Blake, D. R., Bruhwiler, L., Cameron-Smith, P., Castaldi, S., Chevallier, F., Feng, L., Fraser, A., Heimann, M., Hodson, E. L., Houweling, S., Josse, B., Fraser, P. J., Krummel, P. B., Lamarque, J.-F., Langenfelds, R. L., Le Quere, C., Naik, V., O’Doherty, S., Palmer, P. I., Pison, I., Plummer, D., Poulter, B., Prinn, R. G., Rigby, M., Ringeval, B., Santini, M., Schmidt, M., Shindell, D. T., Simpson, I. J., Spahni, R., Steele, L. P., Strode, S. A., Sudo, K., Szopa, S., van der Werf, G. R., Voulgarakis, A., van Weele, M., Weiss, R. F., Williams, J. E., and Zeng, G.: Three decades of global methane sources and sinks, Nat. Geosci., 6, 813-823, 2013.

Kitidis, V., Upstill-Goddard, R. C., and Anderson, L. G.: Methane and nitrous oxide in surface water along the North-West Passage, Arctic Ocean, Mar. Chem., 121, 80-86, 2010.

Kort, E. A., Wofsy, S. C., Daube, B. C., Diao, M., Elkins, J. W., Gao, R. S., Hintsa, E. J., Hurst, D. F., Jimenez, R., Moore, F. L., Spackman, J. R., and Zondlo, M. A.: Atmospheric observations of Arctic Ocean methane emissions up to $82[\mathrm{deg}]$ north, Nat. Geosci., 5, 318-321, 2012.

Kvenvolden, K., Lilley, M. D., and Lorenson, T. D.: The Beaufort Sea Continental Shelf as a seasonal source of atmospheric methane, Geophys. Res. Lett., 20, 2459-2462, 1993.

Lawrence, D. M., Slater, A. G., Tomas, R. A., Holland, M. M., and Deser, C.: Accelerated Arctic land warming and permafrost degradation during rapid sea ice loss, Geophys. Res. Lett., 35, L11506, doi:10.1029/2008g1033985, 2008.

Loose, B., McGillis, W. R., Schlosser, P., Perovich, D., and Takahashi, T.: Effects of freezing, growth, and ice cover on gas trans- 
port processes in laboratory seawater experiments, Geophys. Res. Lett., 36, L05603, doi:10.1029/2008g1036318, 2009.

Lorenson, T. D. and Kvenvolden, K. A.: Methane in coastal seawater, sea ice and bottom sediments, Beaufort Sea, Alaska: U.S. Geological Survey Open-File Report 95-70, US Geological Survey, Menlo Park, CA, 1995.

McGinnis, D. F., Greinert, J., Artemov, Y., Beaubien, S. E., and Wüest, A.: Fate of rising methane bubbles in stratified waters: How much methane reaches the atmosphere?, J. Geophys. Res., 111, C09007, doi:10.1029/2005jc003183, 2006.

Myhre, G., D. Shindell, F.-M. Bréon, W. Collins, J. Fuglestvedt, J. Huang, D. Koch, J.-F. Lamarque, D. Lee, B. Mendoza, T. Nakajima, A. Robock, G. Stephens, T. Takemura, and Zhang, H.: Anthropogenic and Natural Radiative Forcing, Cambridge University Press, Cambridge, United Kingdom and New York, NY, USA, 2013.

Nomura, D., Yoshikawa-Inoue, H., and Toyota, T.: The effect of sea-ice growth on air-sea $\mathrm{CO}_{2}$ flux in a tank experiment, Tellus B, 58, 418-426, 2006.

Nomura, D., Eicken, H., Gradinger, R., and Shirasawa, K.: Rapid Physically driven invesrion of the air-sea ice $\mathrm{CO}_{2}$ flux in the seasonal landfast ice off Barrow, Alaska after onset of surface melt, Cont. Shelf Res., 30, 1998-2004, 2010.

Notz, D. and Worster, M. G.: Desalination processes of sea ice revisited, J. Geophys. Res., 114, C05006, doi:10.1029/2008JC004885, 2009.

O’Connor, F. M., Boucher, O., Gedney, N., Jones, C. D., Folberth, G. A., Coppell, R., Friedlingstein, P., Collins, W. J., Chappellaz, J., Ridley, J., and Johnson, C. E.: Possible role of wetlands, permafrost, and methane hydrates in the methane cycle under future climate change: A review, Rev. Geophys., 48, RG4005, doi:10.1029/2010RG000326, 2010.

Papadimitriou, S., Thomas, D. N., Kennedy, H., Haas, C., Kuosa, H., Krell, A., and Dieckmann, G. S.: Biogeochemical composition of natural sea ice brines from the Weddell Sea during early austral summer, Limnol. Oceanogr., 52, 1809-1823, 2007.

Petrich, C. and Eicken, H.: Growth, Structure and Properties of Sea Ice, in: Sea ice, edited by: Thomas, D. N. and Dieckmann, G. S., Blackwell Publishing Ltd, UK, 2010.

Raynaud, D., Delmas, R., Ascencio, J. M., and Legrand, M.: Gas extraction from polar ice cores: a critical issue for studying the evolution of atmospheric $\mathrm{CO}_{2}$ and ice-sheet surface elevation, Ann. Glaciol., 3, 265-268, 1982.

Reagan, M. T. and Moridis, G. T.: Dynamic response of oceanic hydrate deposits to ocean temperature change, J. Geophys. Res., 113, C12023, doi:10.1029/2008JC004938, 2008.

Romanovskii, N. N., Hubberten, H. W., Gavrilov, A. V., Tumskoy, V. E., Tipenko, G. S., Grigoriev, M. N., and Siegert, C.: Thermokarst and land-ocean interactions, Laptev Sea Region, Russia, Permafrost Periglac., 11, 137-152, 2000.

Savvichev, A. S., Rusanov, I. I., Yusupov, S. K., Pimenov, N. V., Lein, A. Y., and Ivanov, M. V.: The biogeochemical cycle of methane in the coastal zone and littoral of the Kandalaksha Bay of the White Sea, Microbiology+, 73, 457-468, 2004.
Schubert, C. J., Vazquez, F., Lösekann-Behrens, T., Knittel, K., Tonolla, M., and Boetius, A.: Evidence for anaerobic oxidation of methane in sediments of a freshwater system (Lago di Cadagno), FEMS Microbiol. Ecol., 76, 26-38, 2011.

Shakhova, N., Semiletov, I., and Panteleev, G.: The distribution of methane on the Siberian Arctic shelves: Implications for the marine methane cycle, Geophys. Res. Lett., 32, L09601, doi:10.1029/2005GL022751, 2005.

Shakhova, N., Semiletov, I., Salyuk, A., Yusupov, V., Kosmach, D., and Gustafsson, O.: Extensive Methane Venting to the Atmosphere from Sediments of the East Siberian Arctic Shelf, Science, 327, 1246-1250, 2010.

Skoog, D. A., West, D. M., and Holler, F. J.: Chimie analytique, De Boeck Université, Paris, Bruxelles, 1997.

Untersteiner, N.: Natural desalinisation and equilibrium salinity profile of perennial sea ice, J. Geophys. Res., 73, 1251-1257, 1968.

Upstill-Goddard, R. C., Barnes, J., Frost, T., Punshon, S., and Owens, N. J. P.: Methane in the southern North Sea: Low-salinity inputs, estuarine removal, and atmospheric flux, Global Biogeochem. Cy., 14, 1205-1217, 2000.

Weeks, W. F.: On sea ice, University of Alaska Press, Fairbanks, Alaska, 2010.

Westbrook, G. K., Thatcher, K. E., Rohling, E. J., Piotrowski, A. M., Pälike, H., Osborne, A. H., Nisbet, E. G., Minshull, T. A., Lanoisellé, M., James, R. H., Hühnerbach, V., Green, D., Fisher, R. E., Crocker, A. J., Chabert, A., Bolton, C., BeszczynskaMöller, A., Berndt, C., and Aquilina, A.: Escape of methane gas from the seabed along the West Spitsbergen continental margin, Geophys. Res. Lett., 36, L15608, doi:10.1029/2009GL039191, 2009.

Whiticar, M. J.: Carbon and hydrogen isotope systematics of bacterial formation and oxidation of methane, Chem. Geol., 161, 291314, 1999.

Wiesenburg, D. A. and Guinasso, N. L.: Equilibrium solubilities of methane, carbon monoxide and hydrogen in water and sea water, J. Chem. Eng. Data, 24, 356-360, 1979.

Yamamoto, S., Alcauskas, J. B., and Crozier, T. E.: Solubility of methane in distilled water and seawater, J. Chem. Eng. Data, 21, 78-80, 1976.

Zeikus, J. G. and Winfrey, M. R.: Temperature limitation of methanogenesis in aquatic sediments, Appl. Environ. Microb., 31, 99-107, 1976.

Zhou, J., Delille, B., Eicken, H., Vancoppenolle, M., Brabant, F., Carnat, G., Geilfus, N.-X., Papakyriakou, T., Heinesch, B., and Tison, J.-L.: Physical and biogeochemical properties in landfast sea ice (Barrow, Alaska): Insights on brine and gas dynamics across seasons, J. Geophys. Res.-Ocean, 118, 3172-3189, 2013.

Zindler, C., Bracher, A., Marandino, C. A., Taylor, B., Torrecilla, E., Kock, A., and Bange, H. W.: Sulphur compounds, methane, and phytoplankton: interactions along a north-south transit in the western Pacific Ocean, Biogeosciences, 10, 3297-3311, doi:10.5194/bg-10-3297-2013, 2013. 